\title{
Formation of Hybrid Ring Structure of Cyanurate/Isocyanurate in the Reaction between 2,4,6-Tris(4-Phenyl-Phenoxy)-1, 3,5-Triazine and Phenyl Glycidyl Ether
}

\author{
Daisuke Ohno ${ }^{12 *}$, Kazuya Zenyoji ${ }^{3}$, Youji Kurihara², Kazuyoshi Ueda², Hitoshi Habuka² \\ ${ }^{1}$ Advanced Business Research Center, Mitsubishi Gas Chemical Company, Inc., Tokyo, Japan \\ ${ }^{2}$ Division of Materials Science and Engineering, Graduate School of Engineering, Yokohama National University, \\ Yokohama, Japan \\ ${ }^{3}$ MGC Chemical Analysis Center, Mitsubishi Gas Chemical Company, Inc., Tokyo, Japan \\ Email: daisuke-ohno@mgc.co.jp
}

Received 11 March 2016; accepted 31 May 2016; published 3 June 2016

Copyright (C) 2016 by authors and Scientific Research Publishing Inc.

This work is licensed under the Creative Commons Attribution International License (CC BY). http://creativecommons.org/licenses/by/4.0/

c) (i) Open Access

\section{Abstract}

Reaction products of 2,4,6-tris(4-phenyl-phenoxy)-1,3,5-triazine derived from 4-phenylphenol cyanate ester and phenyl glycidyl ether were analyzed. In addition to an isocyanurate compound and an oxazolidone compound which were well known as reaction products of cyanate esters and epoxy resins, compounds with hybrid ring structure of cyanurate/isocyanurate were determined. Gibbs free energies of the compound having hybrid ring structure of cyanurate/isocyanurate with two isocyanurate moiety were found to be lower than that of the compound with cyanurate ring structure through calculations. Calculation data supported the existence of hybrid ring structure of cyanurate/isocyanurate. It was revealed that isomerization from cyanurate to isocyanurate occurs via hybrid ring structure of cyanurate/isocyanurate in the reaction of aryl cyanurate and epoxy.

\section{Keywords}

Thermosetting Resins, Cyanate Ester, Epoxy, Isomerization, Hybrid Ring Structure

\section{Introduction}

Cyanate ester resins have been investigated as high heat resistant thermosetting resins, with applications for

${ }^{*}$ Corresponding author.

How to cite this paper: Ohno, D., Zenyoji, K., Kurihara, Y., Ueda, K. and Habuka, H. (2016) Formation of Hybrid Ring Structure of Cyanurate/Isocyanurate in the Reaction between 2,4,6-Tris(4-Phenyl-Phenoxy)-1, 3,5-Triazine and Phenyl Glycidyl Ether. International Journal of Organic Chemistry, 6, 117-125. http://dx.doi.org/10.4236/ijoc.2016.62013 
various products such as structural composites, printed wiring boards, adhesives and coatings [1]-[4].

Scheme 1 shows reactions of cyanate ester and epoxy. Triazine rings, formed by trimerization of cyanate esters, react with epoxy resins [1] [5]-[7]. Regarding the reaction between cyanate ester resin and epoxy resin, trimerization of the cyanate ester occurs as the first step, forming a cyanurate ring. Then, secondary epoxy insertion into the ether bond of the cyanurate ring occurs [8]. Finally, isomerization from a cyanurate ring to an isocyanurate ring occurs, followed by reaction of another epoxy with isocyanurate, forming an oxazolidone structure [9] [10]. Shimp and co-workers reported the reaction product of p-cumylphenyl cyanate and phenyl glycidyl ether [5]. Korshak and co-workers reported the reaction between triphenylcyanurate and phenyl glycidyl ether [6]. Bauer and co-workers reported the reaction between p-chlorophenyl cyanate and phenyl glycidyl ether [7]. These researches didn't show partial isomerization from an alkyl cyanurate to an alkyl isocyanurate.

In this study, we investigated the reaction products of a compound with a cyanurate ring and a compound with epoxy using 2,4,6-tris(4-phenyl-phenoxy)-1,3,5-triazine and phenyl glycidyl ether as model compounds. From this reaction, we find that partial isomerization occurs, resulting in the formation of a hybrid ring structure of cyanurate/isocyanurate.

\section{Result and Discussion}

Figure 1 shows the HPLC chromatogram of the reaction products, where a and b represent 2,4,6-tris(4-phenylphenoxy)-1,3,5-triazine and phenyl glycidyl ether, respectively. Many reaction products were detected by HPLC. The amount of Mw1035b, Oxiazolidone, Phenyl phenol $+\mathbf{b}$ and UK2 increased by extending the reaction time from $1.5 \mathrm{~h}$ to $11 \mathrm{~h}$.

\section{Trimerization}

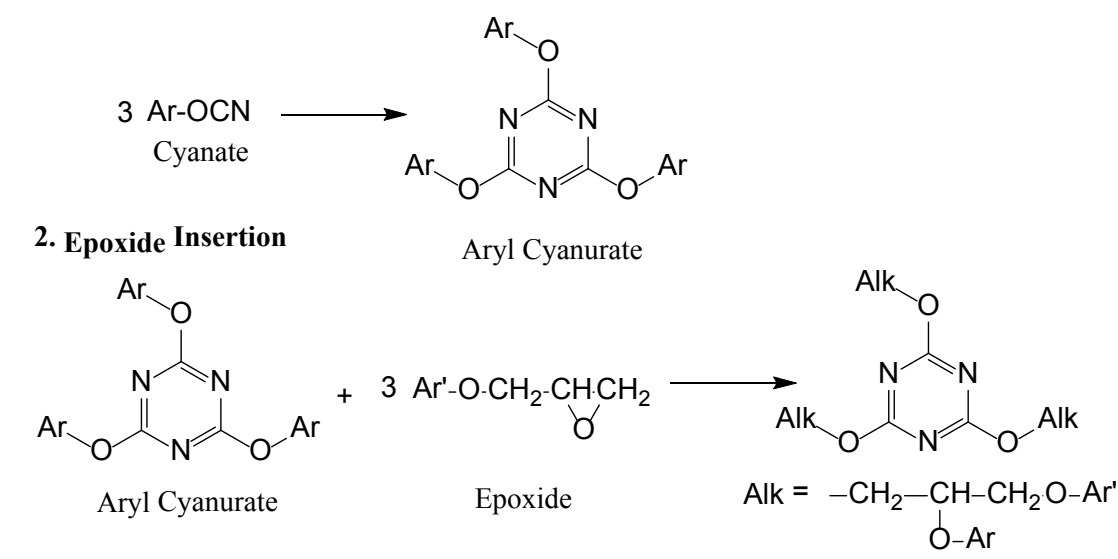

3. Isomerization

Alkyl Cyanurate

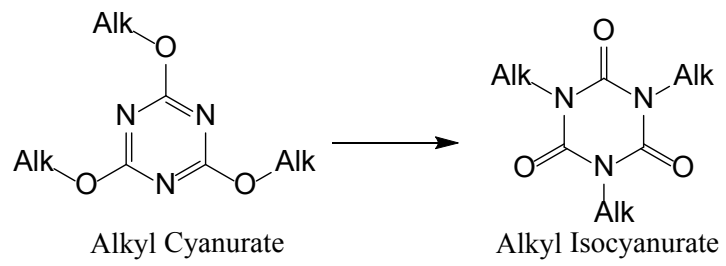

4. Ring Cleavage and Reformation

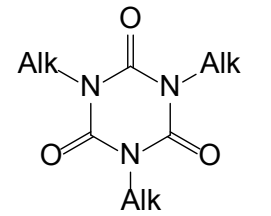

Alkyl Isocyanurate<smiles>COCCO[Mg]</smiles>

Epoxide<smiles>CCOC(=O)N([AlH2])CCO[Ga]</smiles>

Oxazolidone 


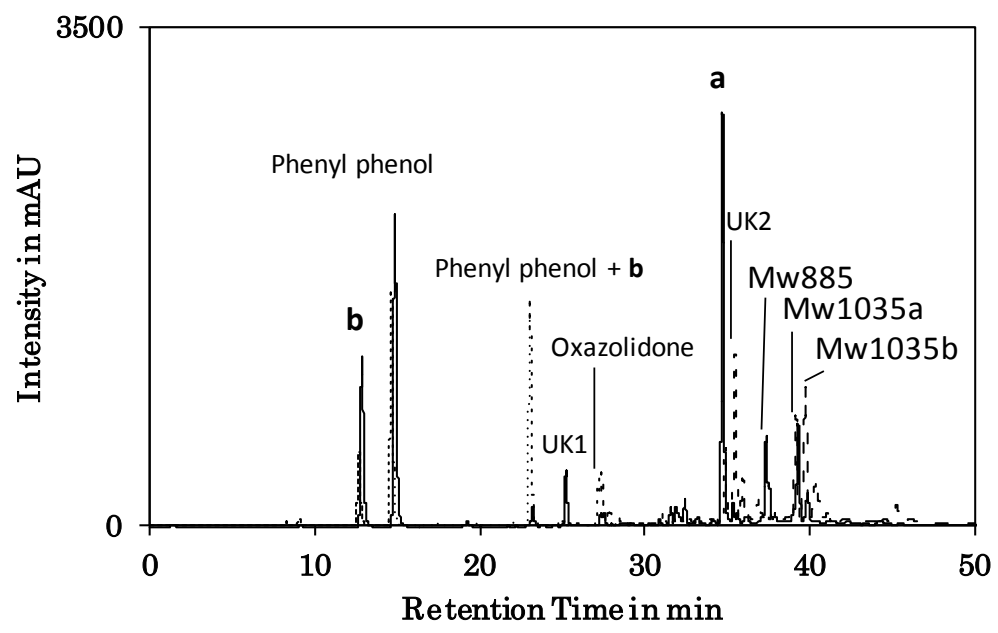

Figure 1. HPLC chromatogram of the reaction products, where a and b represent 2,4,6-tris(4phenyl-phenoxy)-1,3,5-triazine and phenyl glycidyl ether, respectively (solid line: $200^{\circ} \mathrm{C} 1.5 \mathrm{~h}$, dashed line: $200^{\circ} \mathrm{C} 11 \mathrm{~h}$ ).

LC-MS identified three peaks whose molecular weight agreed with the reaction products of a and two or three molecules of $\mathbf{b}$.

The compound with a molecular weight of 885 was equivalent to the molecular weight of the reaction product of $\mathbf{a}$ and two molecules of $\mathbf{b}$. The compounds with molecular weights of 1035 were equivalent to the molecular weight of the reaction product of a and three molecules of $\mathbf{b}$. Figure 2 shows assumed isomers with a molecular weight of 885, and Figure 3 shows assumed isomers with a molecular weight of 1035 .

These three peaks were then separated by preparative HPLC and each chemical structure was analyzed by ${ }^{1} \mathrm{H}$ NMR, ${ }^{1} \mathrm{H}_{-}{ }^{13} \mathrm{C}$ HSQC-NMR, edited ${ }^{1} \mathrm{H}-{ }^{13} \mathrm{C}$ HSQC-NMR and FT-IR.

Figure 4 shows the ${ }^{1} \mathrm{H}$ NMR spectra of the three compounds.

MW1035b had one kind of methine proton (Figure 4). The ratio of proton peak integrations agreed with the reaction product of $\mathbf{a}$ and three molecules of $\mathbf{b}$. In addition, a carbon-oxygen double bond $\left(1697 \mathrm{~cm}^{-1}\right)$ was observed in the FT-IR spectrum. On the basis of these results, MW1035b was determined to be an isocyanurate compound (1035-3 in Figure 3).

MW1035a had three kinds of methine protons (Figure 4). The chemical shifts of two methine protons (4.99 and $5.03 \mathrm{ppm}$ ) were almost identical to those of the methine protons of MW1035b (4.95 ppm). The ratio of aromatic proton peak integrations with those of methine and methylene protons agreed with the reaction product of $\mathbf{a}$ and three molecules of $\mathbf{b}$. Furthermore, the ratio of the three methine proton peak integrations $(\mathrm{CH})$ was 1:1:1. In addition, a carbon-oxygen double bond $\left(1685 \mathrm{~cm}^{-1}\right)$ was found in the FT-IR spectrum. These results indicated that MW1035a has a hybrid ring structure of cyanurate/isocyanurate with two isocyanate moieties (1035-2 in Figure 3).

The ${ }^{1} \mathrm{H}$ NMR spectrum of $\mathbf{M W 8 8 5}$ showed four kinds of methine protons. The ratio of aromatic proton peak integrations with those of methine and methylene protons agreed with the reaction product of a and two molecules of $\mathbf{b}$. The ratio of the four methine proton peak integrations was $0.54: 0.92: 0.37: 0.17$. This ratio does not agree with any compound among the four candidates of MW885 (Figure 2). These results suggested that MW885 was a mixture of isomers. A carbon-oxygen double bond $\left(1685 \mathrm{~cm}^{-1}\right)$ was also found in the FT-IR spectrum. Therefore, it is assumed that $\mathbf{M W 8 8 5}$ also has a hybrid ring structure of cyanurate/isocyanurate.

In the case of triallylcyanurate, Gillham and co-workers proposed the Claisen rearrangement as a possible reaction mechanism of the isomerization [11]. Shmakova and co-workers investigated the transformation on irradiation of triallylcyanurate and poly (vinyl chloride). They proposed hybrid ring structure of cyanurate/isocyanurate by using FI-IR [12]. In the reaction between cyanate ester and epoxy, formation of isocyanurate was mentioned and rearrangement from cyanurate to isocyanurate after completion of epoxy insertion was assumed [2].

Regarding other reaction products, 4-phenylphenol was thought to be a product by hydrolysis of a with water in the air or elimination of phenyl phenol from reaction product of $\mathbf{a}$ and $\mathbf{b}$ [5] [7] [13]. 4-Phenylphenol $+\mathbf{b}$ was 


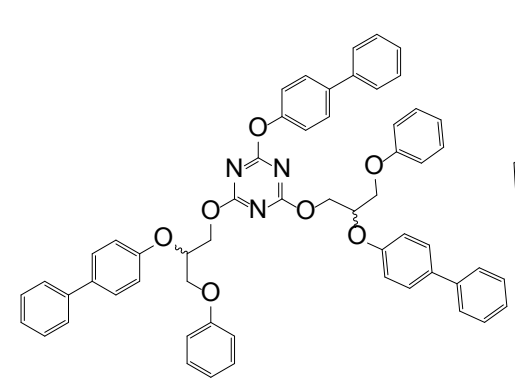

885-0

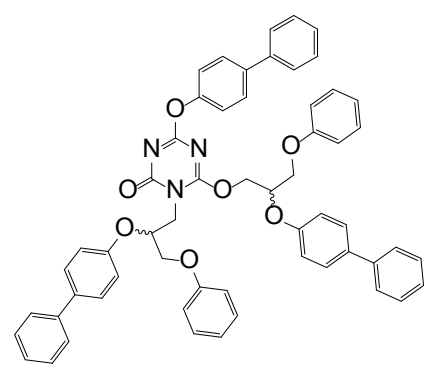

885-1'

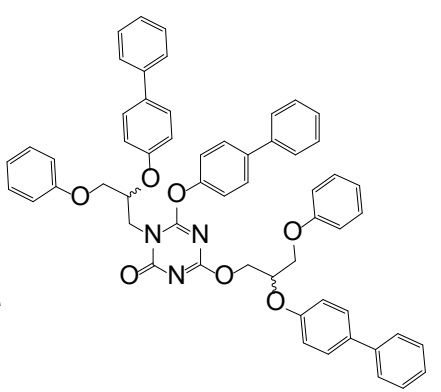

885-1

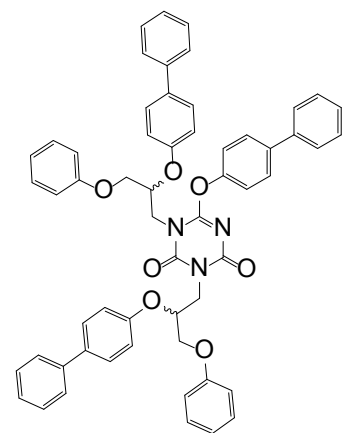

885-2

Figure 2. Molecular structure of assumed isomers with a molecular weight of 885 .

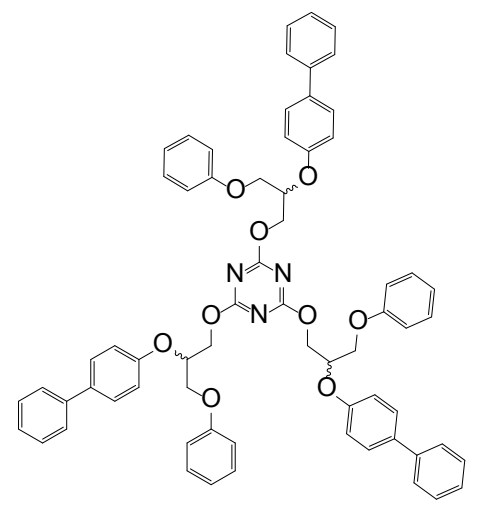

1035-0

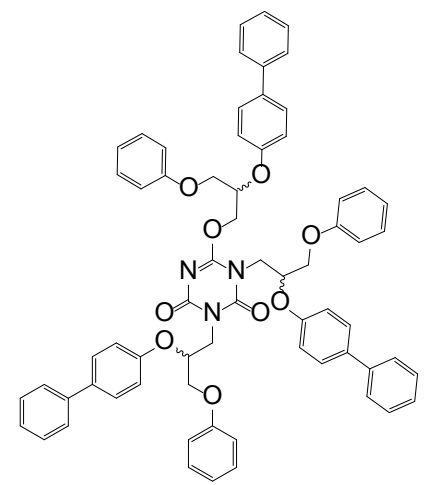

1035-2

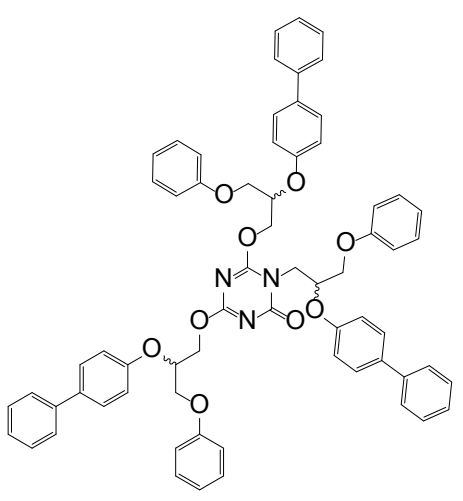

1035-1

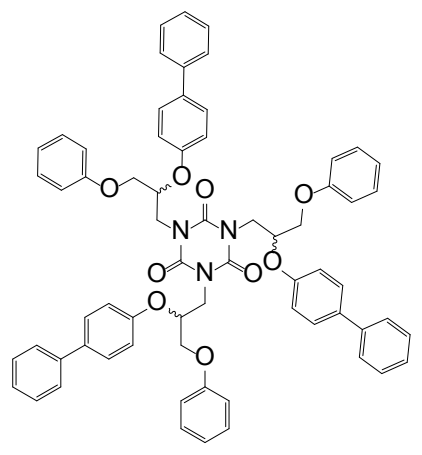

1035-3

Figure 3. Molecular structure of assumed isomers with a molecular weight of 1035 . 


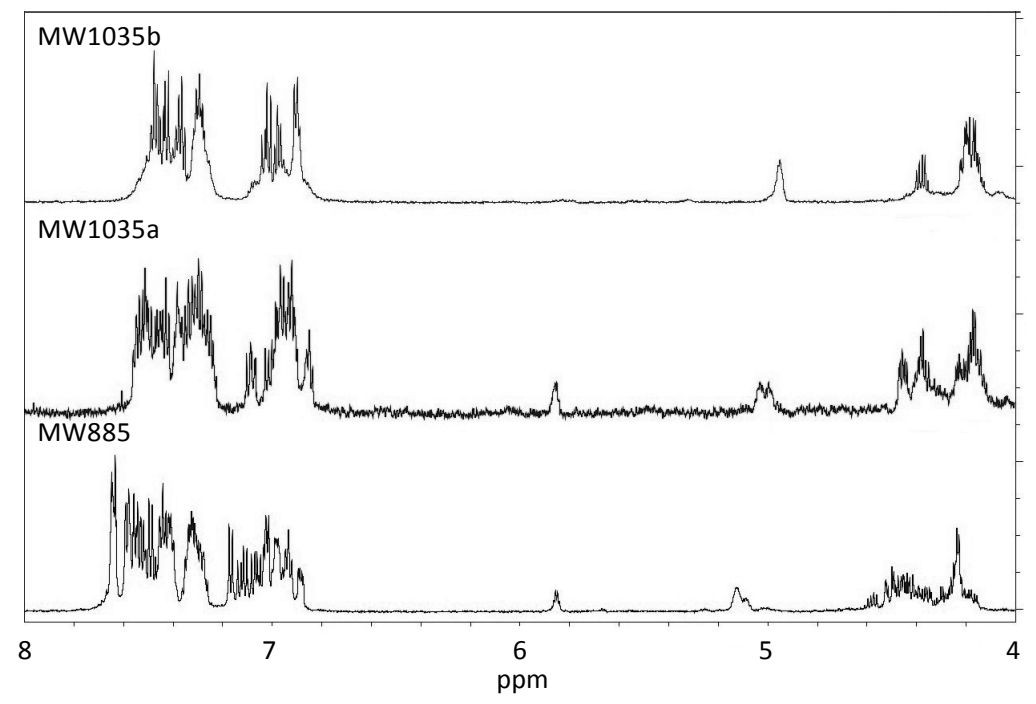

Figure 4. ${ }^{1} \mathrm{H}$ NMR spectra of the three reaction products.

a reaction product of phenyl phenol and $\mathbf{b}$. Formation of oxazolidone was confirmed in the reaction of $\mathbf{a}$ and $\mathbf{b}$ (Scheme 1) [9] [10]. Figure 5 shows the structure of these molecules.

We are conducting further investigation of unknown reaction products (UK1, UK2, and others).

To discuss the partial isomerization from cyanurate to isocyanurate, Gibbs free energies at $298.15 \mathrm{~K}$ and at 1 atm of the assumed reaction products of $\mathbf{a}$ and $\mathbf{b}$ (Figure 2 and Figure 3) were calculated on the optimized structures using Gaussian 09 by using B3LYP/6-31G(d,p) [14]. Chirality of all methine carbon of the assumed products was set as $\mathrm{S}$ in the calculation.

Table 1 and Table 2 show Gibbs free energy of the assumed products of the reaction between $\mathbf{a}$ and $\mathbf{b}$.

Regarding isomers with molecular weight of 885, the Gibbs free energy of 885-2 was lower than that of the other isomers (885-0, 885-1 and 885-1'). Regarding isomers with molecular weight of 1035, the Gibbs free energies of 1035-2 and 1035-3 were lower than that of the other isomers (1035-0 and 1035-1). Free energy decreases sharply when hybrid ring with two isocyanuate moiety forms in both isomers with molecular weights of 885 and 1035. Scheme 2 shows the assumed reaction between $\mathbf{a}$ and $\mathbf{b}$. According to the above discussion, the reaction route via 885-2 and 1035-2 is assumed to be the main route toward isocyanurate $(\mathbf{1 0 3 5 - 3})$ at $200^{\circ} \mathrm{C}$. These calculations result in the supported formation of hybrid ring structure in experiment.

\section{Conclusion}

In conclusion, we investigated the reaction products of 2,4,6-tris(4-phenyl-phenoxy)-1,3,5-triazine (a) and phenyl glycidyl ether (b). We found that partial isomerization occurred in this reaction, forming a hybrid ring structure of cyanurate/isocyanurate. Calculations of Gibbs free energy supported the existence of hybrid ring structure.

\section{Experimental}

4-Phenylphenol cyanate ester was synthesized from 4-phenylphenol by standard procedure [1] [2]. Phenyl glycidyl ether was obtained from Tokyo Chemical Industry Co., Ltd.

To a $100 \mathrm{ml}$ single-neck round bottomed flask with a magnetic stirring bar, 4-Phenylphenol cyanate ester (4.0 $\mathrm{g}, 6.83 \mathrm{mmol})$, toluene $(1.0 \mathrm{~g})$, and zinc 2-ethylhexanoate $(20.0 \mathrm{mg})$ were added and vigorously stirred for $2 \mathrm{~h}$ at $100^{\circ} \mathrm{C}$. The resultant white precipitate was filtered and washed with methyl ethyl ketone and then dried for $8 \mathrm{~h}$ under vacuum at $80^{\circ} \mathrm{C}$. The chemical structure of 2,4,6-tris(4-phenyl-phenoxy)-1,3,5-triazine was determined by nuclear magnetic resonance (NMR) and liquid chromatography-mass spectroscopy (LC-MS).

2,4,6-Tris(4-phenyl-phenoxy)-1,3,5-triazine (a) $(20.1 \mathrm{mg}, 0.0343 \mathrm{mmol})$ and phenyl glycidyl ether (b) (29.4 $\mathrm{mg}, 0.196 \mathrm{mmol}$ ) were placed in a vial. The reaction mixture was then heated at $200^{\circ} \mathrm{C}$ for $1.5 \mathrm{~h}$ or $11 \mathrm{~h}$ with a heating block. a can react with 6 molecules of $\mathbf{b}$ theoretically (Scheme 1) [1] [3]. 


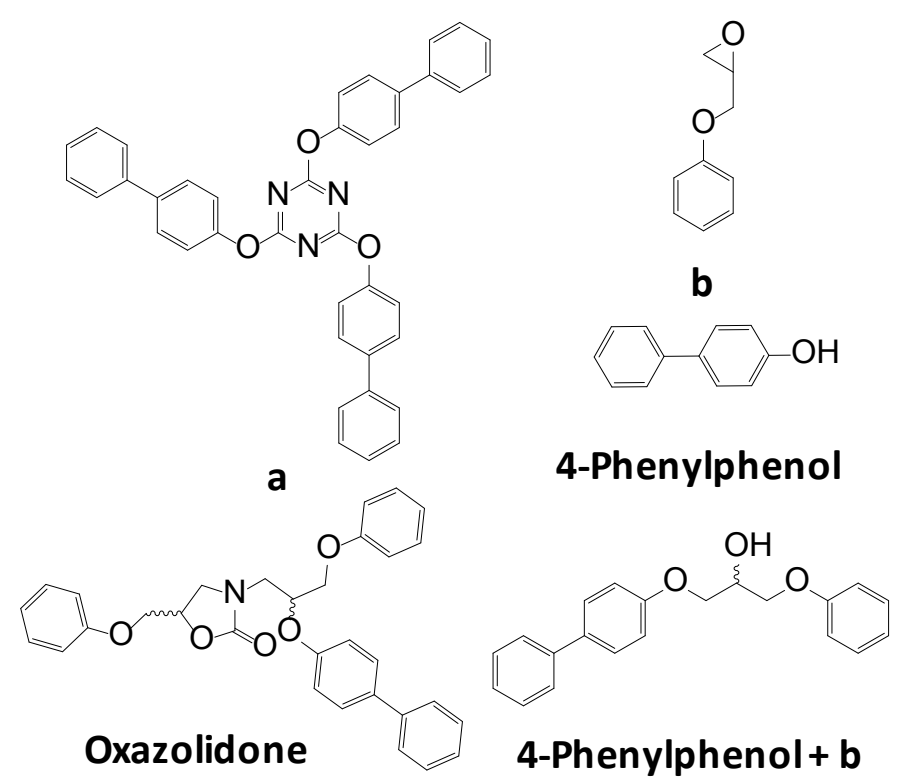

Figure 5. Structure of molecules.

Table 1. Gibbs free energy of isomers with a molecular weight of 885 .

\begin{tabular}{cccc}
\hline Compound & Number of icocyanatemoiety & $\mathrm{G}($ a.u. $)$ & $\Delta \mathrm{G}(\mathrm{kJ} / \mathrm{mol})$ \\
\hline $885-0$ & 0 & -2890.46141 & 0 \\
$885-1$ & 1 & -2890.46812 & -17.61448 \\
$885-1$, & 1 & -2890.45247 & 23.47197 \\
$885-2$ & 2 & -2890.48973 & -74.35679 \\
\hline
\end{tabular}

Table 2. Gibbs free energy of isomers with a molecular weight of 1035.

\begin{tabular}{cccc}
\hline Compound & Number of icocyanatemoiety & $\mathrm{G}($ a.u. $)$ & $\Delta \mathrm{G}(\mathrm{kJ} / \mathrm{mol})$ \\
\hline $1035-0$ & 0 & -3389.72979 & 0 \\
$1035-1$ & 1 & -3389.73289 & -8.14955 \\
$1035-2$ & 2 & -3389.75728 & -72.17499 \\
$1035-3$ & 3 & -3389.78551 & -146.29023 \\
\hline
\end{tabular}

After heating, acetonitrile $(10.1 \mathrm{~g})$ was added to the test tube, and the reaction mixture was dissolved. The solution was then analyzed by high performance LC (HPLC), LC-MS, FD-MS, NMR, and Fourier transform infrared spectroscopy (FT-IR).

HPLC analyses were performed using Waters HP-1100 system with TOSOH ODS-120T column. UV detection was conducted at an absorbance of $274 \mathrm{~nm}$. A mobile phase was a gradient of water and acetonitrile $(50 \%$ to $100 \%$ over $30 \mathrm{~min}$ ). The flow rate was $0.5 \mathrm{~mL} / \mathrm{min}$. Mass spectra were recorded on JEOL JMS-LCmate (LCMS) or JEOL MS-700 (FD-MS). IR spectra were recorded on a Jasco FT/IR-410 spectrometer (KBr). NMR spectra were measured on Buruker spectrometer at $600 \mathrm{MHz}$.

MW885: ${ }^{1} \mathrm{H}$ NMR (600 MHz, $\left.\mathrm{CD}_{3} \mathrm{CN}\right): \delta(\mathrm{ppm}) 4.15$ - $4.59\left(\mathrm{~m}, 8 \mathrm{H}, \mathrm{CH}_{2}\right), 5.01,5.09,5.12,5.85(\mathrm{~s}, 2 \mathrm{H}, \mathrm{CH})$, 6.88 - 7.65 (m, 37H, ArH). HRMS (APCI): $m / z$ calcd for C57H48N3O7: 886.3492 [M + H]+; found: 886.3463 .

MW1035a: ${ }^{1} \mathrm{H}$ NMR $\left(600 \mathrm{MHz}, \mathrm{CD}_{3} \mathrm{CN}\right): \delta(\mathrm{ppm}) 4.12-4.47\left(\mathrm{~m}, 12 \mathrm{H}, \mathrm{CH}_{2}\right), 4.99(\mathrm{~s}, 1 \mathrm{H}, \mathrm{CH}), 5.03(\mathrm{~s}, 1 \mathrm{H}$, $\mathrm{CH}), 5.85(\mathrm{~s}, 1 \mathrm{H}, \mathrm{CH}), 6.83$ - $7.56(\mathrm{~m}, 42 \mathrm{H}, \mathrm{ArH})$. LC-MS (APCI): $m / z$ [M + H]+; found: 1036.1.

MW1035b: ${ }^{1} \mathrm{H}$ NMR $\left(600 \mathrm{MHz}, \mathrm{CD}_{3} \mathrm{CN}\right): \delta(\mathrm{ppm}) 4.13-4.40\left(\mathrm{~m}, 4 \mathrm{H}, \mathrm{CH}_{2}\right), 4.95(\mathrm{~s}, 1 \mathrm{H}, \mathrm{CH}), 6.89-7.50(\mathrm{~m}$, 14H, ArH). LC-MS (APCI): $m / z[\mathrm{M}+\mathrm{H}]+$; found: 1036.2 . 


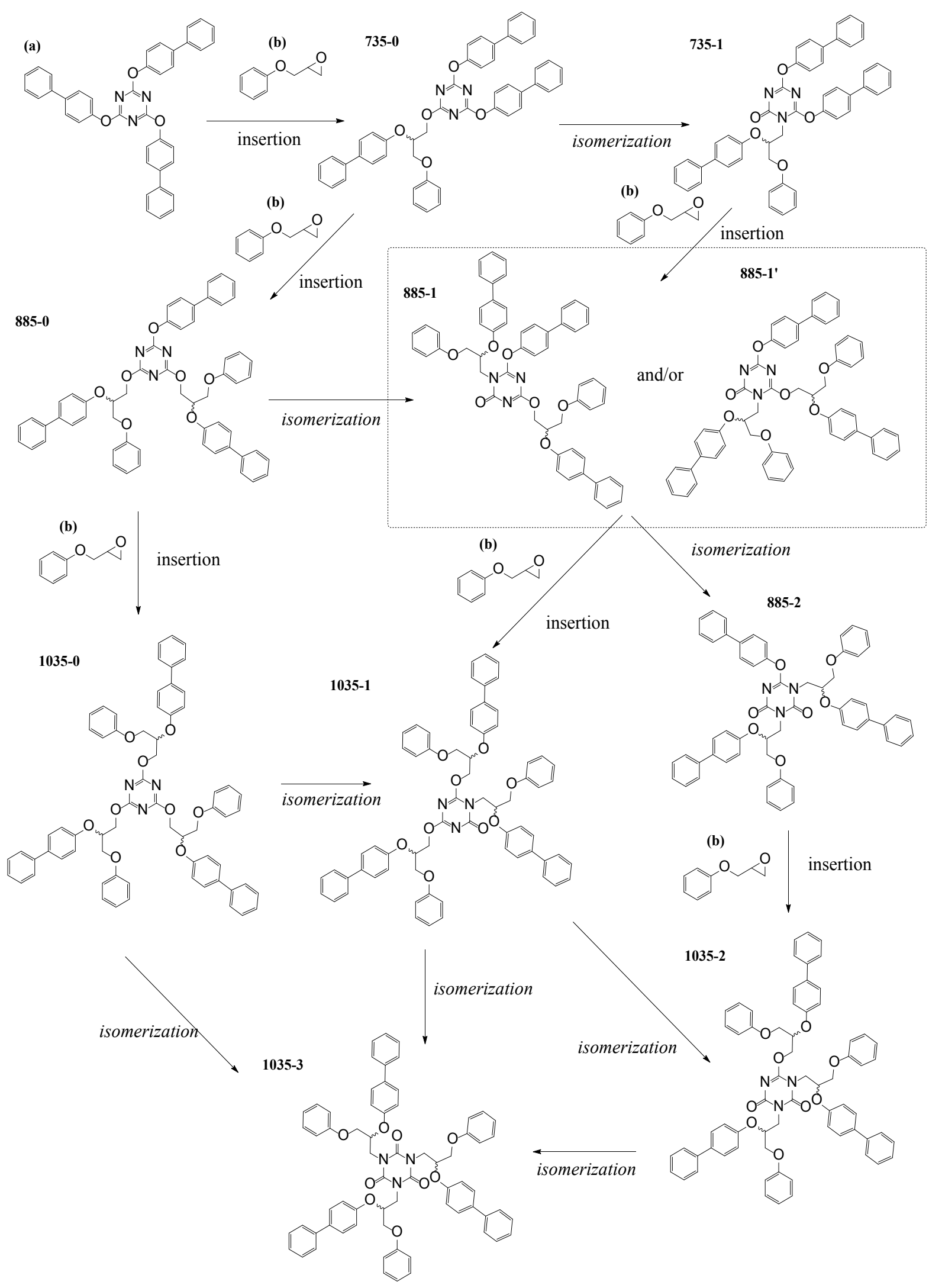

Scheme 2. Assumed reaction between 2,4,6-tris(4-phenyl-phenoxy)-1,3,5-triazine (a) andphenyl glycidyl ether (b). 
Oxazolidone: ${ }^{1} \mathrm{H}$ NMR $\left(600 \mathrm{MHz}, \mathrm{CD}_{3} \mathrm{CN}\right): \delta(\mathrm{ppm}) 3.58-3.86\left(\mathrm{~m}, 4 \mathrm{H}, \mathrm{CH}_{2}\right), 3.97\left(\mathrm{~m}, 1 \mathrm{H}, \mathrm{CH}_{2}\right), 4.07(\mathrm{~m}$, $\left.1 \mathrm{H}, \mathrm{CH}_{2}\right), 4.28\left(\mathrm{~m}, 2 \mathrm{H}, \mathrm{CH}_{2}\right), 4.79(\mathrm{~m}, 1 \mathrm{H}, \mathrm{CH}), 4.98(\mathrm{~m}, 1 \mathrm{H}, \mathrm{CH}), 6.82(\mathrm{~m}, 2 \mathrm{H}, \mathrm{ArH}), 6.97(\mathrm{~m}, 4 \mathrm{H}, \mathrm{ArH}), 7.14$ (m, 2H, ArH), 7.22 (m, 2H, ArH), 7.32 (m, 3H, ArH), 7.45 (m, 2H, ArH), 7.59 (m, 4H, ArH). LC-MS (APCI): $m / z[\mathrm{M}+\mathrm{H}]+$; found: 496.0 .

4-Phenylphenol + b: ${ }^{1} \mathrm{H}$ NMR (600 MHz, $\left.\mathrm{CD}_{3} \mathrm{CN}\right): \delta(\mathrm{ppm}) 4.09-4.21\left(\mathrm{~m}, 4 \mathrm{H}, \mathrm{CH}_{2}\right), 4.29(\mathrm{~m}, 1 \mathrm{H}, \mathrm{CH}), 6.98$ (m, 3H, ArH), 7.06 (m, 2H, ArH), 7.32 (m, 3H, ArH), 7.45 (m, 2H, ArH), 7.61 (m, 4H, ArH) (m, 14H, ArH). MS (FD): $m / z$ [M]+; found: 320.1 .

4-Phenylphenol was identified by using a commercial product (Tokyo Chemical Industry Co., Ltd.).

\section{Acknowledgements}

The computations were performed using Research Center for Computational Science, Okazaki, Japan.

\section{References}

[1] Fang, T. and Shimp, D.A. (1995) Polycyanate Esters: Science and Applications. Progress in Polymer Science, 20, 61118. http://dx.doi.org/10.1016/0079-6700(94)E0006-M

[2] Hamerton, I. and Hay, J.N. (1998) Recent Developments in the Chemistry of Cyanate Esters. Polymer International, 47, 465-473. http://dx.doi.org/10.1002/(SICI)1097-0126(199812)47:4<465::AID-PI88>3.0.CO;2-S

[3] Bershtein, V., Fainleib, A., Egorova, L., Grigoryeva, O., Kirilenko, D., Konnikov, S., Ryzhov, V., Starostenko, O., Yakushev, P., Yagovkina, M. and Saiter, J.M. (2015) The Impact of Ultra-Low Amounts of Introduced Reactive POSS Nanoparticles on Structure, Dynamics and Properties of Dense Cross-Linked Cyanate Ester Resins. European Polymer Journal, 67, 128-142. http://dx.doi.org/10.1016/j.eurpolymj.2015.03.022

[4] Lin, C.H., Yang, K.Z., Leu, T.S., Lin, C.H. and Sie, J.W. (2006) Synthesis, Characterization, and Properties of Novel Epoxy Resins and Cyanate Esters. Journal of Polymer Science, Part A: Polymer Chemistry, 44, 3487-3502. http://dx.doi.org/10.1002/pola.21453

[5] Shimp, D.A. and Wentworth, J.E. (1992) Cyanate Ester-Cured Epoxy Resin Structural Composites. Proceedings of the 37th International SAMPE Symposium, Anaheim, 9-12 March 1992, 293-305.

[6] Korshak, V.V., Pankratov, V.A., Komarva, L.I., Frenkel, T.M., Fainleib, A.M. and Vinogradova, S.V. (1983) Reaction of Cyanurates with the Epoxide Ring. Bulletin of the Academy of Science of the USSR, Division of Chemical Science, 32, 2135-2138.

[7] Bauer, M., Tänzer, W., Much, H. and Ruhman, R. (1989) Reaktionen polyfunktioneller cyansäureester mit polyfunktionellen Glycidethern. 1. Identifizierung der gebildeten Strukturelemente. Acta Polymerica, 40, 335-340. http://dx.doi.org/10.1002/actp.1989.010400509

[8] Nishikubo, T., Kameyama, A. and Saito, C. (2000) A Novel Polyadditon of Bis(Epoxide)s with Triazinediaryl Ether for the Synthesis of Poly(Ether)s Containing Triazine Group in the Main Chain. Journal of Polymer Science, Part A: Polymer Chemistry, 38, 3604-3611. http://dx.doi.org/10.1002/1099-0518(20001001)38:19<3604::AID-POLA160>3.0.CO;2-5

[9] Okumoto, S. and Yamabe, S. (2001) A Computational Study of Base-Catalyzed Reactions between Isocyanates and Epoxides Affording 2-Oxazolidones and Isocyanurates. Journal of Computational Chemistry, 22, 316-326. http://dx.doi.org/10.1002/1096-987X(200102)22:3<316::AID-JCC1004>3.0.CO;2-5

[10] Martin, M.D., Ormaetxea, M., Harismendy, I., Remiro, P.M. and Mondragon, I. (1999) Cure Chemo-Rheology of Mixtures Based on Epoxy Resins and Ester Cyanates. European Polymer Journal, 35, 57-68. http://dx.doi.org/10.1016/S0014-3057(98)00095-0

[11] Gillham, J.K. and Mentzer, C.C. (1973) Thermosetting Reactions: Thermochemical Reactions of Triallylcyanurate and Triallylisocyanurate. Journal of Applied Polymer Science, 17, 1143-1164. http://dx.doi.org/10.1002/app.1973.070170412

[12] Shmakova, N.A., Feldman, V.I. and Sukhov, F.F. (2001) IR Spectroscopic Study of Chemical Transformations upon Irradiation of the Poly(Vinyl Chloride)-Triallylcyanurate System. High Energy Chemistry, 35, 224-228. http://dx.doi.org/10.1023/A:1017628410368

[13] Kasehagen, L.J., Haury, I., Macosko, C.W. and Shimp, D.A. (1997) Hydrolysis and Blistering of Cyanate Ester Networks. Journal of Applied Polymer Science, 64, 107-113. http://dx.doi.org/10.1002/(SICI)1097-4628(19970404)64:1<107::AID-APP9>3.0.CO;2-S

[14] Frisch, M.J., Trucks, G.W., Schlegel, H.B., Scuseria, G.E., Robb, M.A., Cheeseman, J.R., Scalmani, G., Barone, V., Mennucci, B., Petersson, G.A., Nakatsuji, H., Caricato, M., Li, X., Hratchian, H.P., Izmaylov, A.F., Bloino, J., Zheng, 
G., Sonnenberg, J.L., Hada, M., Ehara, M., Toyota, K., Fukuda, R., Hasegawa, J., Ishida, M., Nakajima, T., Honda, Y., Kitao, O., Nakai, H., Vreven, T., Montgomery, J.A., Peralta Jr., J.E., Ogliaro, F., Bearpark, M., Heyd, J.J., Brothers, E., Kudin, K.N., Staroverov, V.N., Kobayashi, R., Normand, J., Raghavachari, K., Rendell, A., Burant, J.C., Iyengar, S.S., Tomasi, J., Cossi, M., Rega, N., Millam, J.M., Klene, M., Knox, J.E., Cross, J.B., Bakken, V., Adamo, C., Jaramillo, J., Gomperts, R., Stratmann, R.E., Yazyev, O., Austin, A.J., Cammi, R., Pomelli, C., Ochterski, J.W., Martin, R.L., Morokuma, K., Zakrzewski, V.G., Voth, G.A., Salvador, P., Dannenberg, J.J., Dapprich, S., Daniels, A.D., Farkas, Ö., Foresman, J.B., Ortiz, J.V., Cioslowski, J. and Fox, D.J. (2009) Gaussian 09 (Revision D.01). Gaussian, Inc., Wallingford. 